\title{
X-ray Diffraction Characterization and Battery Performances of Fiber-type Li-Mn-O Electrode for Li-ion Battery
}

\section{Jinhan YAO, ${ }^{a}$ Tomoaki TAKASAKI, ${ }^{b, *}$ Kazuya NISHIMURA, ${ }^{b}$ Takashi MUKAI, ${ }^{a}$ and Tetsuo SAKAI ${ }^{a}, *$}

\author{
a National Institute of Advanced Industrial Science and Technology, Ikeda, Osaka 563-8577, Japan \\ b Kawasaki Heavy Industries, Gigacell Battery Center, Akashi, Hyogo 673-8666, Japan \\ *Corresponding authors: sakai-tetsuo@aist.go.jp, takasaki_t@khi.co.jp
}

\section{ABSTRACT}

A fiber-type $\mathrm{Li}-\mathrm{Mn}-\mathrm{O}$ electrode was developed for use as the positive electrode of Li-ion batteries. For the electrode preparation process, a $\mathrm{Mn}_{3} \mathrm{O}_{4}$ layer was formed on a carbon fiber by electrodeposition, and then the $\mathrm{Mn}_{3} \mathrm{O}_{4}$ plated fiber was hydrothermally treated in a $\mathrm{LiOH}$ aqueous solution. A structural analysis based on the synchrotron X-ray diffraction pattern indicated that the hydrothermally-treated sample contains $70 \mathrm{wt} \%$ orthorhombic $\mathrm{LiMnO}_{2}$ phases in addition to the $15 \mathrm{wt} \%$ cubic $\mathrm{LiMn}_{2} \mathrm{O}_{4}$ ones. After cycling, the electrode consisted of $78 \mathrm{wt} \% \mathrm{LiMn}_{2} \mathrm{O}_{4}$ and $6 \mathrm{wt} \%$ $\mathrm{LiMnO}_{2}$ phases, indicating that the $\mathrm{LiMnO}_{2}$ phases were transformed into the $\mathrm{LiMn}_{2} \mathrm{O}_{4}$ ones during the cycling.

(c) The Electrochemical Society of Japan, All rights reserved.

Keywords : $\mathrm{LiMnO}_{2}, \mathrm{LiMn}_{2} \mathrm{O}_{4}$, Fiber-type Electrode, Li-ion Battery

\section{Introduction}

The demand for Li-ion batteries is gradually increasing from a hybrid electric vehicle (HEV) and plug-in HEV to large-scale socialinfrastructures such as railway systems and stabilization of natural power generation. ${ }^{1}$ Enhancement in the high-power performance and long-cycle life is one of the crucial issues in order to realize its widespread use in industrial applications.

At present, an aluminum (Al) foil is typically used for the positive current collector of the Li-ion battery. In general, a slurry consisting of the active material powder, binder material and conductive additive is coated on the $\mathrm{Al}$ foil substrate. In order to improve the Li-ion battery performance, a three dimensional (3D) micro-battery design, in which a number of electrodes is configured in a non-planar geometry, offers a solution for the high-rate performance due to the increased electrode/electrolyte interface efficiency. ${ }^{2,3}$ These advanced $3 \mathrm{D}$ electrode configurations would lead to enhanced battery performances.

Previously, fiber-type $\mathrm{Ni}(\mathrm{OH})_{2}$ electrodes were developed for the Ni-MH battery. ${ }^{4,5}$ Test cells containing several thousand $\mathrm{Ni}(\mathrm{OH})_{2}$ coated fibers as the cathode exhibited better high-rate and cycle-life performances than those of the conventional one. However, for the $\mathrm{Ni}-\mathrm{MH}$ battery, it is very difficult to prepare the fiber-type negative electrodes due to the complex alloy compositions. In order to develop both positive and negative fiber-type electrodes, we became interested in the Li-ion battery, in which there are various materials available for both electrodes.

We have recently developed both negative and positive fibertype electrodes for the Li-ion battery. ${ }^{6,7}$ For the positive electrode, the Al-substituted Li-Mn-O oxide, which is a low cost and low toxicity material, was prepared by electrodeposition and a hydrothermal reaction. In this report, the charge and discharge performances of the fiber-type $\mathrm{Li}-\mathrm{Mn}-\mathrm{O}$ electrode without $\mathrm{Al}$ addition was investigated. In order to investigate the capacity-reduction mechanism of the fiber-type Li-Mn-O electrode, a synchrotron X-ray diffraction analysis was carried out for the as-prepared and cycled electrodes.

\section{Experimental}

\subsection{Positive fiber-type electrode preparation}

In order to prepare the fiber-type $\mathrm{Li}-\mathrm{Mn}-\mathrm{O}$ positive electrode, a carbon fiber tow (Toho Tenax Co., Ltd.) with 12,000 single fibers was used as the collector substrate. For the 1st step, an electrodeposition was galvanostatically $\left(5-10 \mathrm{~mA} \mathrm{~cm}^{-2}\right)$ carried out using an automatic polarization system (HZ-5000, Hokuto Denko Co., Ltd.) in a bath containing $0.1 \mathrm{~mol} \mathrm{dm}{ }^{-3} \mathrm{Mn}\left(\mathrm{NO}_{3}\right)_{2}$. During the $2 \mathrm{nd}$ step, the Mn-O deposited fibers were hydrothermally treated in a $3 \mathrm{~mol} \mathrm{dm}^{-3} \mathrm{LiOH}$ aqueous solution in an autoclave at $110^{\circ} \mathrm{C}$ for $20 \mathrm{~h}$. The obtained Li-Mn-O coated fiber-tow was used as the positive electrode. Figure 1 shows a schematic view of the fiber-type $\mathrm{Li}-\mathrm{Mn}-\mathrm{O}$ electrode forming process. The electrodes were washed with deionized water and dried at $70^{\circ} \mathrm{C}$ for $20 \mathrm{~h}$. The amount of the $\mathrm{Li}-\mathrm{Mn}-\mathrm{O}$ was determined from the weight difference before and after the deposition.

The X-ray diffraction (XRD) measurements $(\lambda=1.54 \AA)$ were performed by an $\mathrm{X}$-ray diffractometer using $\mathrm{Cu}-\mathrm{K} \alpha$ radiation (M06XCE, MAC science). The synchrotron XRD measurements ( $\lambda=0.7 \AA$ ) were performed using the beam line BL19B2 at the synchrotron radiation facility, SPring-8, Japan. A large Debye-

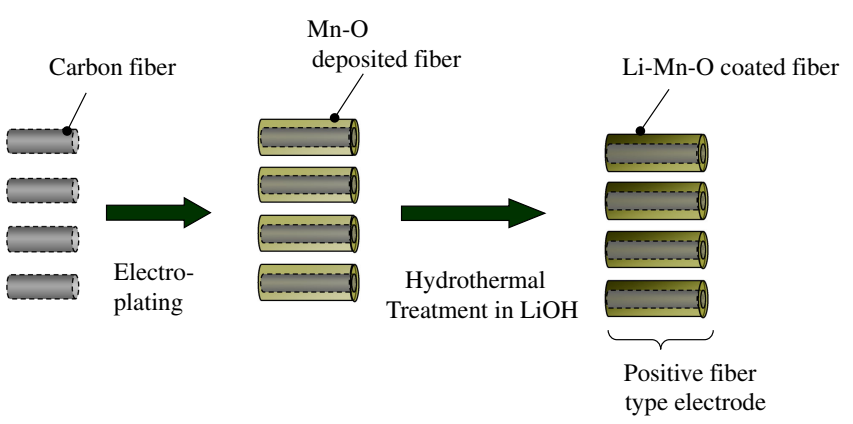

Figure 1. (Color online) Schematic preparation procedure for LiMn-O based fiber-type electrode. 


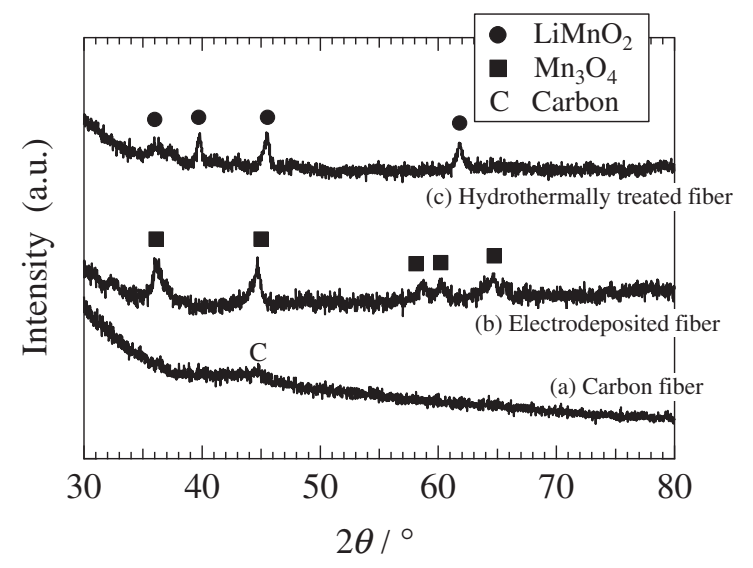

Figure 2. XRD patterns of (a) bare carbon fiber, (b) Mn-O coated ones and (c) Li-Mn-O coated ones.

Scherrer camera was used to detect the fine diffraction patterns. The fiber-type electrodes were cut into small pieces, then loaded into glass capillaries with $0.3 \mathrm{~mm} \phi$ inner diameters. The structural analysis was carried out using the Rietveld program, RIETAN$2000 .^{8}$

The electrochemical properties of the prepared Li-Mn-O electrode were evaluated using a laminate half-cell with a $\mathrm{Li}$ film $(0.5 \mathrm{~mm}$ thickness, Honjo Metal) as the counter electrode. The Li$\mathrm{Mn}-\mathrm{O}$ coated carbon fiber tow was attached to an $\mathrm{Al}$ strip as the cathode, and heat-treated in a vacuum at $150^{\circ} \mathrm{C}$ for $2 \mathrm{~h}$ before the half-cell assembly. The electrolyte was $1 \mathrm{M} \mathrm{LiPF}_{6}$ in a mixture of ethylene carbonate (EC) and diethyl carbonate (DEC), 1:1 v/v (Kishida Chemicals). All cycling tests were performed at $30^{\circ} \mathrm{C}$ at a current density of $0.2 \mathrm{C}\left(\sim 30 \mathrm{~mA} \mathrm{~g}^{-1}\right)$.

\section{Results and Discussion}

\subsection{Characterizations of as-prepared Li-Mn-O electrodes}

Figure 2 shows the XRD patterns for the bare carbon fiber, Mn-O deposited fiber and hydrothermally-treated $\mathrm{Mn}-\mathrm{O}$ fiber. No obvious characteristic peaks were observed for the bare carbon fiber as shown in Fig. 2(a). For the electrodeposited fiber in Fig. 2(b), the peaks are indexed to the $\mathrm{Mn}_{3} \mathrm{O}_{4}$ phase. After the hydrothermal treatment, the diffraction peaks can be indexed to the orthorhombic $\mathrm{LiMnO}_{2}$ phase as shown in Fig. 2(c). These results suggest that the $\mathrm{Mn}_{3} \mathrm{O}_{4}$ deposited on the carbon fiber was transformed into $\mathrm{LiMnO}_{2}$ during the hydrothermal treatment.

Figure 3 shows the charge and discharge curves of the hydrothermally treated Li-Mn-O fiber-type electrode at the 1st, 50th and 100th cycles. The initial charge and discharge capacity was approximately 160 and $155 \mathrm{mAhg}^{-1}$, respectively, within the $2.5-$ $4.2 \mathrm{~V}$ voltage range. Two potential plateaus were observed in the discharge curves. The lower potential plateau at $3 \mathrm{~V}$ gradually decreased during the 100 cycles. Meanwhile, the higher potential plateau at $4 \mathrm{~V}$ was maintained after cycling.

Figure 4 shows the high-rate discharge curves of the fiber-type Li-Mn-O electrode. After charging at the $0.2 \mathrm{C}$ rate, the electrode was discharged at various currents ranging from the 1 to $10 \mathrm{C}$ rate. At the $0.2 \mathrm{C}$ rate, the electrode exhibited an approximate 130 $\mathrm{mAhg}^{-1}$ discharge capacity. An approximate $80 \mathrm{mAhg}^{-1}$ was delivered at the $10 \mathrm{C}$ rate.

The fiber-type Li-Mn-O electrode shows charge and discharge curves similar to the conventional platy electrode using the hydrothermally-synthesized $\mathrm{LiMnO}_{2}$ powder. In particular, the discharge behaviors, such as voltage reduction and capacities in the 3 and $4 \mathrm{~V}$ regions, bear a close resemblance to each other. ${ }^{9-11}$ The hydrothermally synthesized $\mathrm{LiMnO}_{2}$ is easily activated. Even for the

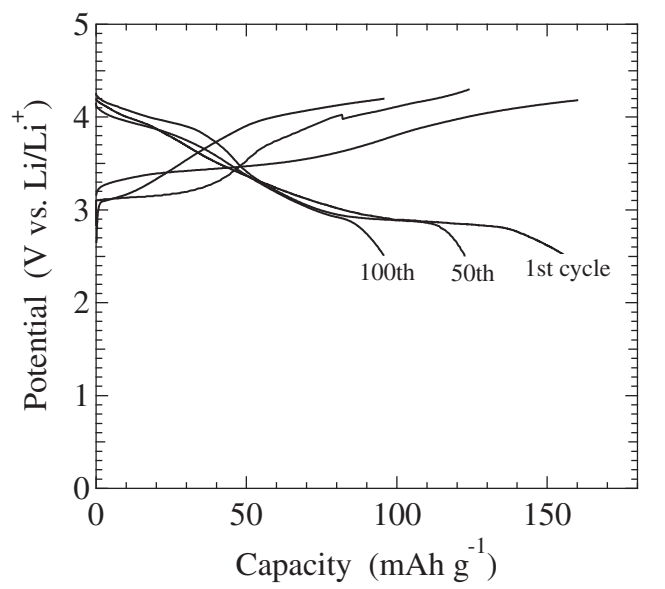

Figure 3. Charge and discharge curves of Li-Mn-O fiber-type electrode.

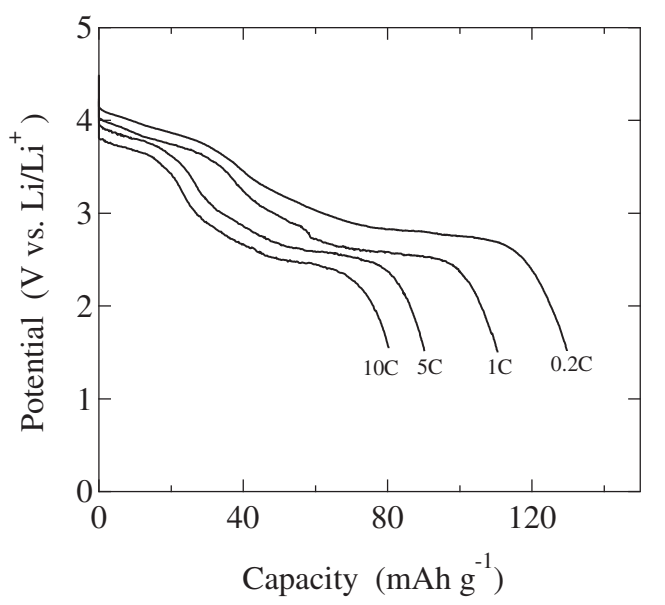

Figure 4. Rate performance of Li-Mn-O fiber-type electrode.

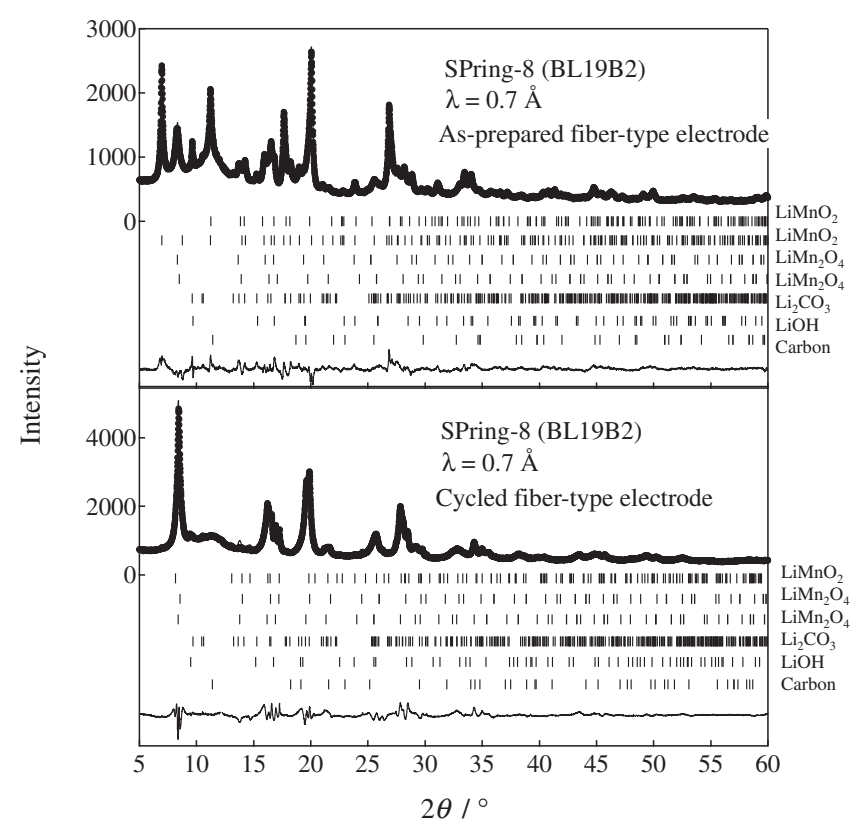

Figure 5. Synchrotron XRD patterns of Li-Mn-O fiber-type electrodes before and after cycling. 
Table 1. Phase components, $R$ values and cell parameters obtained from the Rietveld refinements using synchrotron XRD data for as-prepared and cycled Li-Mn-O carbon fiber-type electrode.

(a) As-prepared $\mathrm{R}_{\mathrm{wp}}=6.36 \%, \mathrm{R}_{\mathrm{p}}=4.93 \%, \mathrm{R}_{\mathrm{e}}=4.14 \%$

\begin{tabular}{|c|c|c|c|c|c|c|}
\hline Phase & $\mathrm{R}_{\mathrm{B}}$ & $\mathrm{R}_{\mathrm{F}}$ & $\begin{array}{l}\text { Space group } \\
\text { (no.) }\end{array}$ & $\begin{array}{l}\text { Abundance } \\
\text { (wt } \%)\end{array}$ & $\begin{array}{c}\text { Cell parameters } \\
(\AA)\end{array}$ & $\begin{array}{l}\text { Volume } \\
\left(\AA^{3}\right)\end{array}$ \\
\hline $\mathrm{LiMnO}_{2}$ & 3.19 & 1.32 & Pmm2 (25) & 26.5 & $\begin{aligned} a & =2.8436(6) \\
b & =5.805(1) \\
c & =4.6097(8)\end{aligned}$ & 76.10 \\
\hline $\mathrm{LiMnO}_{2}$ & 3.20 & 1.39 & Pmmn (59) & 44.3 & $\begin{array}{l}a=4.557(2) \\
b=5.856(8) \\
c=2.863(3)\end{array}$ & 76.43 \\
\hline $\mathrm{LiMn}_{2} \mathrm{O}_{4}$ & 3.08 & 1.30 & Fd-3m (227) & 12.7 & $a=8.412(3)$ & 595.25 \\
\hline $\mathrm{LiMn}_{2} \mathrm{O}_{4}$ & 2.81 & 1.14 & Fd-3m (227) & 1.6 & $a=8.253(4)$ & 562.19 \\
\hline $\mathrm{Li}_{2} \mathrm{CO}_{3}$ & 4.74 & 1.64 & C2/c (15) & 1.8 & $\begin{array}{l}a=8.48(1) \\
b=5.003(4) \\
c=6.275(5) \\
\beta=114.54(8)\end{array}$ & 242.40 \\
\hline $\mathrm{LiOH}$ & 14.11 & 3.38 & P4/nmm (129) & 2.3 & $\begin{array}{l}a=3.422(3) \\
c=4.171(3)\end{array}$ & 48.86 \\
\hline Carbon & 1.96 & 0.95 & P63/mmc (194) & 10.8 & $\begin{array}{l}a=2.51(2) \\
c=7.10(2)\end{array}$ & 38.83 \\
\hline
\end{tabular}

(b) Cycled Li-Mn-O $\mathrm{R}_{\mathrm{wp}}=7.68 \%, \mathrm{R}_{\mathrm{p}}=5.71 \%, \mathrm{R}_{\mathrm{e}}=3.73 \%$

\begin{tabular}{ccccccc}
\hline Phase & $\mathrm{R}_{\mathrm{B}}$ & $\mathrm{R}_{\mathrm{F}}$ & $\begin{array}{c}\text { Space group } \\
\text { (no.) }\end{array}$ & $\begin{array}{c}\text { Abundance } \\
(\mathrm{wt} \%)\end{array}$ & $\begin{array}{c}\text { Cell parameters } \\
(\AA)\end{array}$ & $\begin{array}{c}\text { Volume } \\
\left(\AA^{3}\right)\end{array}$ \\
\hline $\mathrm{Li}_{2} \mathrm{Mn}_{2} \mathrm{O}_{4}$ & 3.72 & 2.15 & I41/amd (141) & 5.8 & $\begin{array}{c}a=5.747(2) \\
c=9.327(6)\end{array}$ & 308.12 \\
\hline $\mathrm{LiMn}_{2} \mathrm{O}_{4}$ & 4.40 & 2.23 & Fd-3m (227) & 22.0 & $a=8.0986(9)$ & 531.17 \\
\hline $\mathrm{LiMn}_{2} \mathrm{O}_{4}$ & 3.58 & 2.25 & Fd-3m (227) & 56.4 & $a=8.2380(9)$ & 559.08 \\
\hline & & & & $\begin{array}{l}a=8.42(3) \\
b=4.90(7)\end{array}$ & 234.58 \\
$\mathrm{Li}_{2} \mathrm{CO}_{3}$ & 4.82 & 2.35 & $\mathrm{C} 2 / \mathrm{c}(15)$ & 2.8 & $\begin{array}{l}c=6.25(5) \\
\beta=114.7(5)\end{array}$ & \\
\hline $\mathrm{LiOH}$ & 4.78 & 2.77 & $\mathrm{P} 4 / \mathrm{nmm}(129)$ & 2.3 & $\begin{array}{l}a=3.398(6) \\
b=4.218(7)\end{array}$ & 48.72 \\
\hline $\mathrm{Carbon}$ & 4.84 & 2.36 & $\mathrm{P} 63 / \mathrm{mmc}(194)$ & 10.7 & $\begin{array}{l}a=2.54(4) \\
c=7.03(1)\end{array}$ & 39.59 \\
\hline
\end{tabular}

conventional platy electrode, the maximum discharge capacity was obtained after 5-10 cycles. Meanwhile, for the fiber-type electrode, the maximum value was observed at the 1 st cycle. The electrical and ionic conduction of the fiber-type electrode were improved, namely, this electrode structure would be more advantageous for the electrochemical reaction than the conventional structure.

The discharge capacity of the fiber-type electrode decreased to $80 \%$ of the initial capacity at the 50th cycle. Meanwhile, the platy electrodes maintained their initial capacity after 20 cycles, and their capacity retention exhibited $75-100 \%$ of the initial capacity even at the 50th cycle. ${ }^{9-15}$ The capacity retention of the fiber-type Li-Mn-O electrode is comparable or lower than that of the conventional ones.

The fiber-type Li-Mn-O positive electrode exhibited better highrate discharge performances than the typical high-temperature sintered powder material. ${ }^{12}$ The electrochemical performance of the large-sized particles is improved by the synthesis temperature ${ }^{12}$ and grinding treatment. ${ }^{13}$ The conventional electrode consisting of the single $\mathrm{LiMn}_{2} \mathrm{O}_{4}$ phase exhibited a good high-rate discharge performance at the $10-15 \mathrm{C}$ rate, ${ }^{16,17}$ maintaining 3.6-4 $\mathrm{V}$ discharge voltage even at the $10 \mathrm{C}$ rate. Meanwhile, for the fiber-type Li-Mn-O electrode, an approximate $3.8 \mathrm{~V}$ higher-voltage region was observed even at the $10 \mathrm{C}$ rate.

Figures 5(a) and 5(b) show the synchrotron XRD patterns for the as-prepared and cycled fiber-type Li-Mn-O electrodes, respectively. Table 1 summarizes the refinement results. The as-prepared electrode contains orthorhombic $\mathrm{LiMnO}_{2}$ and cubic $\mathrm{LiMn}_{2} \mathrm{O}_{4}$ phases. In addition, small amounts of $\mathrm{LiOH}$ and $\mathrm{Li}_{2} \mathrm{CO}_{3}$ were identified, which could be originating from the alkaline solution used for the hydrothermal treatment. After 100 cycles, the electrode mainly consisted of cubic $\mathrm{LiMn}_{2} \mathrm{O}_{4}$. The refinement result indicated that the orthorhombic $\mathrm{LiMnO}_{2}$ phases were replaced by cubic phases during cycling. It is known that the $\mathrm{LiMnO}_{2}$ and $\mathrm{LiMn}_{2} \mathrm{O}_{4}$ phases exhibit 3 and $4 \mathrm{~V}$ discharge voltages, respectively. ${ }^{18}$ The two discharge plateaus at 4 and $3 \mathrm{~V}$ could be due to the reaction associated with $\mathrm{Mn}^{4+} \rightarrow \mathrm{Mn}^{3.5+}$ in $\mathrm{MnO}_{2} \rightarrow \mathrm{LiMn}_{2} \mathrm{O}_{4}$ and $\mathrm{Mn}^{3.5+} \rightarrow \mathrm{Mn}^{3+}$ in 
$\mathrm{LiMn}_{2} \mathrm{O}_{4} \rightarrow \mathrm{LiMnO}_{2}$, respectively. The observed structural change suggests that the latter reaction decreased during cycling, causing the reduction of the $3 \mathrm{~V}$ discharge plateau. The discharge capacity with the $4 \mathrm{~V}$ plateau was maintained even after 100 cycles, indicating that the spinel $\mathrm{LiMn}_{2} \mathrm{O}_{4}$ phase exhibits a reversible charge and discharge reaction on the carbon fiber-type substrate.

After cycling, the tetragonal $\mathrm{Li}_{2} \mathrm{Mn}_{2} \mathrm{O}_{4}$ phase was confirmed in addition to the cubic $\mathrm{LiMn}_{2} \mathrm{O}_{4}$ ones. The tetragonal one could be formed during the discharge in the $3 \mathrm{~V}$ plateau region during the 100th cycle. In the case of the spinel $\mathrm{LiMn}_{2} \mathrm{O}_{4}$ phase, the average valence of $\mathrm{Mn}^{3.5+}$ is the result when $\mathrm{Mn}^{3+}$ and $\mathrm{Mn}^{4+}$ randomly occupy the Mn sites. For the tetragonal structure, the increased JahnTeller ion $\left(\mathrm{Mn}^{3+}\right)$ leads to distortion of the cubic geometry and the formation of a tetragonal cell. The refinement results indicated that the discharge capacity reduction is ascribed to the structural change from the orthorhombic $\mathrm{LiMnO}_{2}$ to cubic $\mathrm{LiMn}_{2} \mathrm{O}_{4}$ rather than the active material separation from the carbon fiber.

\section{Conclusions}

A fiber-type Li-Mn-O electrode was developed by the combined electrodeposition and hydrothermal method. This electrode exhibited a $155 \mathrm{mAhg}^{-1}$ discharge capacity during the 1 st cycle. After 100 cycles, the discharge capacity decreased to an approximate $100 \mathrm{mAh} \mathrm{g}^{-1}$. For the two discharge plateaus at 3 and $4 \mathrm{~V}$, the lower one decreased during the 100 cycles. The synchrotron XRD analysis indicated that the reaction associated with $\mathrm{Mn}^{3.5+} \rightarrow \mathrm{Mn}^{3+}$ in $\mathrm{LiMn}_{2} \mathrm{O}_{4} \rightarrow \mathrm{LiMnO}_{2}$ decreased during cycling, causing the reduction of the $3 \mathrm{~V}$ discharge plateau. The $4 \mathrm{~V}$ plateau with a low capacity at the 100th cycle would be ascribed to the $\mathrm{Mn}^{4+} \rightarrow$ $\mathrm{Mn}^{3.5+}$ in $\mathrm{MnO}_{2} \rightarrow \mathrm{LiMn}_{2} \mathrm{O}_{4}$.

\section{Acknowledgment}

The authors thank Dr. M. Sato and Mr. T. Matsumoto at the Japan Synchrotron Radiation Research Institute (JASRI) for the synchrotron XRD measurements.

\section{References}

1. T. Sakai, Funtai Gijutsu, 2(3), 17 (2010). [in Japanese]

2. R. W. Hart, H. S. White, B. Dunn, and D. R. Rolison, Electrochem. Commun., 5, 120 (2003).

3. P. L. Taberna, S. Mitra, P. Poizot, P. Simon, and J.-M. Tarascon, Nat. Mater, 5, 567 (2006).

4. T. Takasaki, K. Nishimura, T. Mukai, T. Iwaki, K. Tsutsumi, and T. Sakai, J. Electrochem. Soc., 159, A1891 (2012).

5. T. Takasaki, K. Nishimura, T. Mukai, T. Iwaki, K. Tsutsumi, and T. Sakai, J. Electrochem. Soc., 160, A1 (2013).

6. J. Yao, T. Takasaki, K. Nishimura, T. Mukai, and T. Sakai, J. Electrochem. Soc., 160, A980 (2013).

7. J. Yao, K. Nishimura, T. Mukai, T. Takasaki, K. Tsutsumi, K.-F. Aguey-Zinsou, and T. Sakai, ECS Electrochem. Lett., 1, A83 (2012).

8. F. Izumi and T. Ikeda, Mater. Sci. Forum, 321-324, 198 (2000).

9. S.-T. Myung, S. Komaba, and N. Kumagai, Electrochim. Acta, 47, 2387 (2002).

10. M. Wu, Q. Zhang, H. Lu, and A. Chen, Solid State Ionics, 169, 47 (2004).

11. H. Ji, G. Yang, X. Miao, and A. Hong, Electrochim. Acta, 55, 3392 (2010).

12. Z. P. Guo, G. X. Wang, K. Konstantinov, H. K. Liu, and S. X. Dou, J. Alloys Compd., 346, 255 (2002).

13. Y. S. Lee, Y. K. Sun, K. Adachi, and M. Yoshio, Electrochim. Acta, 48, 1031 (2003).

14. C.-H. Lu and H.-C. Wang, J. Eur. Ceram. Soc., 24, 717 (2004).

15. S.-T. Myung, S. Komaba, and N. Kumagai, Solid State Ionics, 150, 199 (2002).

16. J.-W. Lee, J.-I. Kim, and K. C. Roh, Solid State Sci., 14, 1251 (2012).

17. C.-H. Zheng, X. Liu, Z.-F. Wu, Z.-D. Chen, and D.-L. Fang, Electrochim. Acta, 111, 192 (2013).

18. T. Ohzuku, M. Kitagawa, and T. Hirai, J. Electrochem. Soc., 137, 769 (1990). 